\title{
Metabolic Control of Klebsiella pneumoniae mRNA Degradation by the Availability of Fixed Nitrogen
}

\author{
By DANIEL KAHN†, MARIE HAWKINS AND ROBERT R. EADY* \\ $A R C$ Unit of Nitrogen Fixation, University of Sussex, Falmer, Brighton BNI 9RQ, U.K.
}

(Received 9 March 1982)

\begin{abstract}
The chemical and functional stability of Klebsiella pneumoniae mRNAs was dependent on the nitrogen status of the organism. During exponential growth on $\mathrm{N}_{2}$ or $\mathrm{NH}_{4}^{+}$as $\mathrm{N}$-source the halflives of mRNAs were 10 and $4 \mathrm{~min}$, respectively. When $\mathrm{NH}_{4}^{+}$-grown cells were starved of $\mathrm{NH}_{4}^{+}$ for $3 \mathrm{~h}$, under which conditions the nitrogen fixation (nif) genes were derepressed, the half-life of mRNAs increased to $20 \mathrm{~min}$. Addition of $\mathrm{NH}_{4}^{+}$to such $\mathrm{N}$-starved suspensions rapidly destabilized mRNAs with a resultant half-life of $9 \mathrm{~min}$. This destabilization occurred even in the presence of transcription inhibitors, which indicated metabolic control of mRNA degradation. Under most conditions studied the functional decay of nif-specific mRNAs paralleled the decay of bulk mRNAs.
\end{abstract}

\section{INTRODUCTION}

Prokaryotic messenger RNAs are generally unstable with half-lives ranging from 1.5 to $5 \mathrm{~min}$ (Schlessinger, 1972). This contrasts with the known stability of various eukaryotic mR NAs and is believed to facilitate the rapid adaptation of bacteria to abrupt changes in their environment. The occurrence of more stable mRNAs in prokaryotes has nevertheless been reported (Pollock, 1963; Lindahl \& Forchhammer, 1969; Hirashima \& Inouye, 1973; Ikemura et al., 1979), particularly under conditions of energy source shift down (Jacobson \& Jen-Jacobson, 1980) or amino acid starvation (Forchhammer \& Kjeldgaard, 1967; Leal, 1976; Sanchez de Rivas \& Mendez, 1977). In Escherichia coli mRNA half-life remains contant at growth rates between 0.6 and 2.5 doublings $\mathrm{h}^{-1}$ (Pato \& von Meyenburg, 1970). Here we report that in the closely related bacterium Klebsiella pneumoniae, mRNA half-life changed dramatically between growth rates of 0.23 and 0.63 doublings $\mathrm{h}^{-1}$.

When nitrogen becomes growth limiting for free-living $\mathrm{N}_{2}$-fixing bacteria, nitrogenase is derepressed (Brill, 1979). $\mathrm{N}$-starvation causes a severe metabolic stress that the cell must overcome in order to synthesize nitrogenase and resume growth. Important physiological changes are therefore expected to occur. We and others have observed a stringent response of $K$. pneumoniae under N-starvation (Kleiner \& Phillips, 1980; Riesenburg \& Kari, 1981; D. Kahn, M. Hawkins \& R. R. Eady, unpublished observations). Under these conditions there is a rise of the ppGpp pool and a decrease in the rate of stable RNA synthesis. Here we report that during $\mathrm{N}$-starvation, $\mathrm{mRNAs}$ in $K$. pneumoniae were unusually stable, and present data indicating that mRNA degradation was under metabolic control. The effect of $\mathrm{N}$-status on the stability of mRNAs exhibited by non-growing suspensions was also shown by exponentially growing cells. $\mathrm{N}_{2}$-grown cultures of $K$. pneumoniae possessed more stable mRNAs than $\mathrm{NH}_{4}^{+}$-grown cultures. The nifHDK and nifJ mRNAs exhibited a similar behaviour to bulk mRNAs when $K$. pneumoniae was shifted from $\mathrm{N}$-starvation to $\mathrm{N}$-sufficiency. A preliminary report of some of this work was given by Eady et al. (1981).

\footnotetext{
† Present address: Institut National de la Recherche Agronomique, Laboratoire de Biologie Moleculaire des Relations Plantes-Microorganisms, Chemin de Borde-Rouge-Auzeville, 31320 Castanet-Tolosan BP 12, France.
} 


\section{METHODS}

Bacterial growth. Klebsiella pneumoniae strain M5al was grown anaerobically on ammonium (as $1.5 \mathrm{~g}$ $\left(\mathrm{NH}_{4}\right)_{2} \mathrm{SO}_{4} 1^{-1}$ ) or on $\mathrm{N}_{2}$ in $\mathrm{N}$-free medium (NFDM) (Cannon et al., 1974) at $30^{\circ} \mathrm{C} . \mathrm{N}$-starved suspensions were prepared by collecting an $\mathrm{NH}_{4}^{+}$-grown stationary culture by centrifugation, resuspending it in NFDM plus sodium aspartate $\left(0 \cdot 1 \mathrm{~g}^{-1}\right)$ under argon, and incubating it at $30^{\circ} \mathrm{C}$ with shaking in a flask with a rubber closure; $\mathrm{mRNA}$ stability experiments were performed $3 \mathrm{~h}$ later, at which time nif derepression was in the steady state. All the cultures contained between $0 \cdot 1$ and $0 \cdot 2 \mathrm{~g}$ protein $\mathrm{l}^{-1}$.

Measurement of $m R N A$ stability. (a) Chemical decay. RNAs were labelled in vivo by supplementing cultures with $2 \mu \mathrm{M}-\left[{ }^{3} \mathrm{H}\right]$ uridine $\left(5-10 \mu \mathrm{Ci} \mathrm{ml}^{-1}\right)$. After a suitable time interval (1-7 min depending on conditions) proflavine $\left(50 \mu \mathrm{g} \mathrm{ml}^{-1}\right)$ was added to stop further transcription and $0.5 \mathrm{ml}$ samples were removed at intervals for determination of tritiated RNA as described by Bremer \& Yuan (1968). For analysis, unstable RNA was obtained by subtracting the final plateau value corresponding to stable RNA. A semi-log replot of unstable RNA as a function of time gave the chemical half-life of unstable RNA. The efficiency of proflavine as a transcription inhibitor was verified in a control experiment.

(b) Functional decay. Rifampicin $\left(0 \cdot 2 \mathrm{~g}^{-1}\right)$ was added to the culture to stop the initiation of transcription and $1 \mathrm{ml}$ samples were removed at intervals and pulse-labelled for $2 \mathrm{~min}$ at $30^{\circ} \mathrm{C}$ with $2.5 \mu \mathrm{Ci}(92.5 \mathrm{kBq})^{14} \mathrm{C}$-labelled amino acids (specific activity $1.85 \mathrm{GBq}$ milliatom ${ }^{-1}$ ) (CFB104, Amersham). Protein synthesis was stopped with chloramphenicol $\left(0 \cdot 1 \mathrm{~g}^{-1}\right)$ and samples were kept on ice; cells were collected by centrifugation, resuspended in $0 \cdot 1 \mathrm{ml}$ ORTEC sample buffer (Cannon, 1980) and left for $4 \mathrm{~min}$ in a boiling water bath. Debris was sedimented by centrifugation and $10 \mu \mathrm{l}$ portions from the supernatants assayed for radioactive TCA-precipitable material. This measured the rate of protein synthesis. A semi-log plot of the rate of protein synthesis versus time gave the functional half-life of mRNA. The efficiency of rifampicin as a transcription inhibitor was verified in a control experiment.

(c) Functional decay of nif specific mRNAs. ${ }^{14} \mathrm{C}$ pulse-labelled proteins were prepared as described above and analysed for $n i f$-specific polypeptides by SDS-PAGE (Laemmli, 1970). The gel was dried, autoradiographed and the film scanned (wavelength $440 \mathrm{~nm}$, slit $0.1 \mathrm{~mm}$ ). The peaks corresponding to nif-specific polypeptides were integrated, allowing quantification of their rates of synthesis (Merrick et al., 1978; Elmerich et al., 1978; Roberts et al., 1978). A semi-log plot of their rates of synthesis versus time gave the functional half-lives of nif mRNAs.

\section{RESULTS}

Influence of $N$-status on the chemical stability of $K$. pneumoniae mRNAs

During exponential $\mathrm{NH}_{4}^{+}$-supported growth (growth rate, $\mu=0.63 \mathrm{~h}^{-1}$ ), mRNAs turned over rapidly, with a half-life of $4 \pm 1$ min (Fig. $1 a, d$ ). If an $\mathrm{NH}_{4}^{+}$-grown culture was $\mathrm{N}$-starved, mRNAs proved much more stable. After $3 \mathrm{~h}$ of $\mathrm{N}$-starvation, mRNAs turned over with a halflife of $20 \pm 2 \mathrm{~min}$ (Fig. $1 b, e$ ). Control cell suspensions treated similarly, but not subjected to $\mathrm{N}$ starvation, showed the usual short half-life of mRNAs characteristic of $\mathrm{NH}_{4}^{+}$-grown cultures (data not shown). During exponential $\mathrm{N}_{2}$-supported growth $\left(\mu=0.23 \mathrm{~h}^{-1}\right)$, mRNA stability was intermediate (half-life $10 \pm 1 \mathrm{~min}$ ) between that observed during conditions of $\mathrm{N}$ starvation and in $\mathrm{NH}_{4}^{+}$-supported growth (Fig. $1 c, f$ ).

\section{Influence of $N$-status on the functional stability of $K$. pneumoniae $m R N A s$}

The functional half-lives of mRNAs of $\mathrm{N}_{2}$-grown, $\mathrm{NH}_{4}^{+}$-grown and $\mathrm{N}$-starved cultures were obtained as described above (Fig. 2). They were in good agreement with the corresponding chemical half-lives (Table 1).

\section{Influence of added $\mathrm{NH}_{4}^{+}$on $\mathrm{mRNA}$ stability in $\mathrm{N}$-deprived cultures}

Since we observed significant differences in the stability of $m$ RNAs in N-starved suspensions and $\mathrm{NH}_{4}^{+}$-grown cultures of $K$. pneumoniae, the question arose as to how the organism would respond to a change of $\mathrm{N}$-status. To investigate this we labelled an $\mathrm{N}$-starved suspension for 5 min with $\left[{ }^{3} \mathrm{H}\right]$ uridine and then added $\mathrm{NH}_{4}^{+}$together with proflavine to stop further transcription. Samples were removed at intervals for measurement of tritiated RNA (Fig. 3). The half-life of $\mathrm{mRNAs}$ was then $9 \pm 1 \mathrm{~min}$.

Similar experiments using pulse-labelling of proteins with ${ }^{14} \mathrm{C}$-labelled amino acids after the addition of rifampicin and $\mathrm{NH}_{4}^{+}$yielded a functional half-life of $11 \pm 1 \mathrm{~min}$ (Fig. $4 b$ ). Thus, 


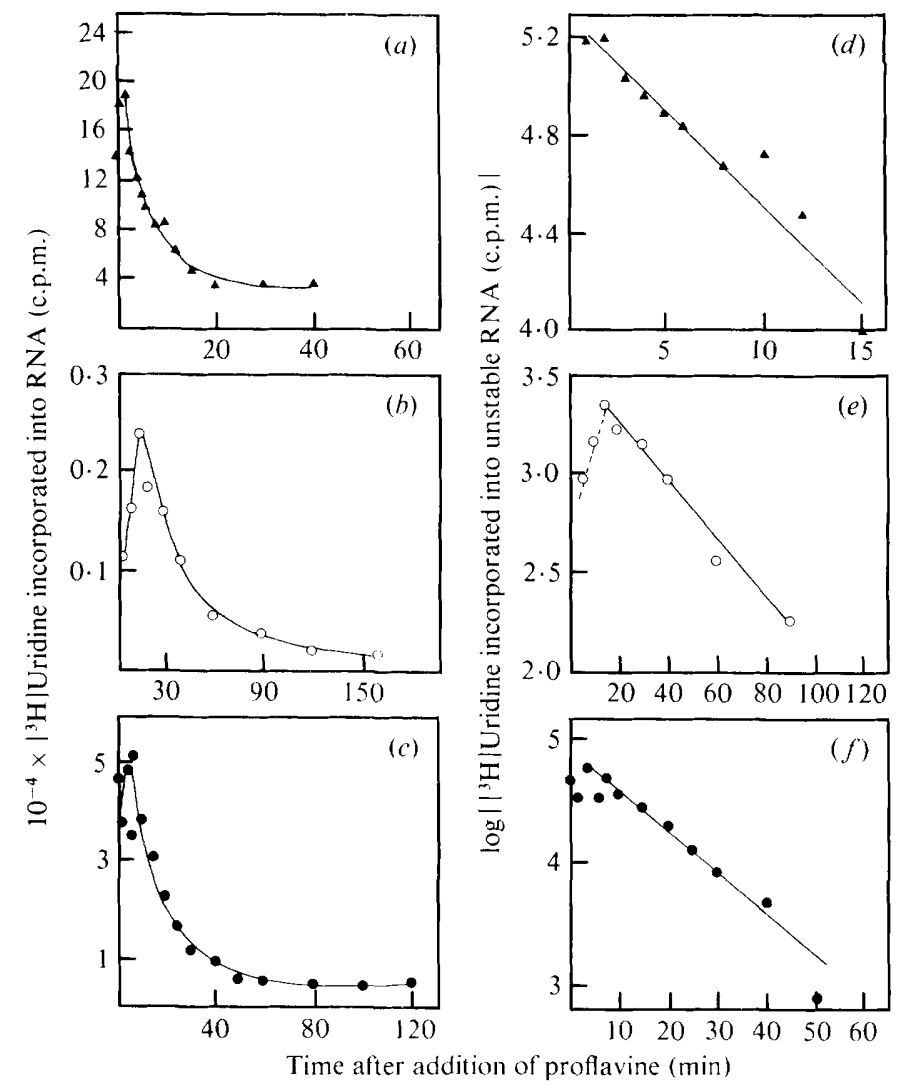

Fig. 1. Chemical stability of mRNAs in $K$. pneumoniae under conditions of different $\mathrm{N}$-status. Bacteria were grown anaerobically at $30^{\circ} \mathrm{C}$ with either $\mathrm{N}_{2}$ or $\mathrm{NH}_{4}^{+}$as $\mathrm{N}$-source as indicated. $\mathrm{N}$-starved suspensions were prepared by harvesting an $\mathrm{NH}_{4}^{+}$-grown stationary culture as described in Methods, and RNA stability was determined after $3 \mathrm{~h}$ of $\mathrm{N}$-starvation. RNA was labelled in vivo with $2 \mu \mathrm{M}$ $\left[{ }^{3} \mathrm{H}\right]$ uridine. At the end of the labelling period proflavine was added to stop transcription and samples were removed at intervals for estimation of ${ }^{3} \mathrm{H}$-labelled RNA as described by Bremer \& Yuan (1968). (a) $\mathrm{NH}_{4}^{+}$-grown culture; $(b) \mathrm{N}$-starved organisms; $(c) \mathrm{N}_{2}$-grown culture; curves $(d),(e)$ and $(f)$ are the respective semi-logarithmic plots of the unstable RNA under these conditions.

addition of $\mathrm{NH}_{4}^{+}$to an $\mathrm{N}$-starved suspension of $K$. pneumoniae resulted in a rapid acceleration of mRNA degradation, This occurred in the absence of de novo RNA synthesis. Hence, mRNA degradation was controlled by the metabolic status of $K$. pneumoniae as determined by the availability of fixed nitrogen.

\section{Functional stability of nif $m R N A$ s during nitrogen starvation}

In $K$. pneumoniae the nif $H D K Y$ operon codes for the nitrogenase polypeptides and the nif $Y$ product of unknown function (Klipp \& Pühler, 1981). The nifJ gene encodes a protein of molecular weight 120000 (Merrick et al., 1978; Elmerich et al., 1978; Roberts et al., 1978). The polypeptides encoded by nif $H$, nif $D$, nif $K$ and nif $J$ are readily detected on electrophoretograms. Protein pulse-labelling followed by SDS-PAGE and autoradiography allows quantification of the coding capacity for the polypeptides encoded by these genes (Fig. $4 a$ ). After the addition of rifampicin, the rates of synthesis of these polypeptides decayed with the half-lives shown in Table 1. During $\mathrm{N}$-starvation, the nif $H D K$ and nif $J$ mRNAs turned over at the same rate as bulk mRNAs with functional half-lives near $23 \mathrm{~min}$. Upon addition of $\mathrm{NH}_{4}^{+}$, with or without rifampicin, these mRNAs decayed at an accelerated rate with a half-life of 5-12 min (Fig. $4 b$ and Table 1). Thus addition of $\mathrm{NH}_{4}^{+}$to suspensions of $K$. pneumoniae during nif derepression 


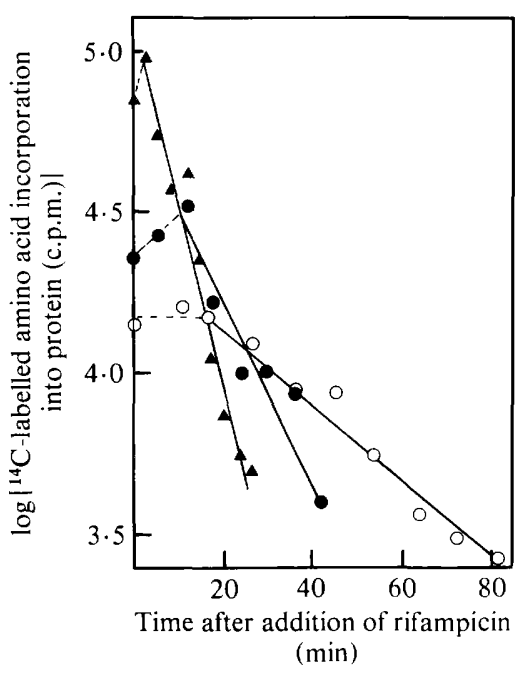

Fig. 2.

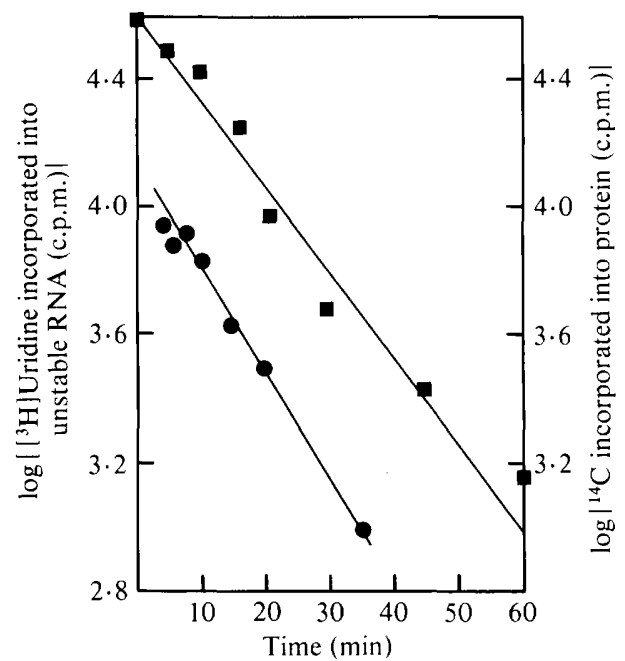

Fig. 3

Fig. 2. Functional stability of mRNAs in $K$. pneumoniae under conditions of different $\mathrm{N}$-status. Initiation of transcription was inhibited by the addition of rifampicin, and at various times samples were removed and pulse-labelled for $2 \mathrm{~min}$ with a mixture of ${ }^{14} \mathrm{C}$-labelled amino acids. TCAprecipitable radioactivity was determined as described in Methods. Semi-logarithmic plots of the rate of protein synthesis in $\mathrm{NH}_{4}^{+}$-grown cultures $(\boldsymbol{A}), \mathrm{N}$-starved organisms $(\mathrm{O})$ and $\mathrm{N}_{2}$-grown cultures $(\boldsymbol{O}$ were used to estimate the functional half-life of bulk mRNA.

Fig. 3. Effect of added $\mathrm{NH}_{4}^{+}$on the stability of mRNA in $\mathrm{N}$-starved $K$. pneumoniae. After $3 \mathrm{~h} \mathrm{~N}$ starvation of a suspension of $K$. pneumoniae, $\left(\mathrm{NH}_{4}\right)_{2} \mathrm{SO}_{4}\left(1.5 \mathrm{mg} \mathrm{ml}^{-1}\right)$ was added together with proflavine or rifampicin, and the chemical $(O)$ and functional $(\boldsymbol{\square})$ stabilities of bulk mRNAs determined as described in the legends of Fig. I and Fig. 2. The half-lives for mRNA stability so obtained are compared with untreated $\mathrm{N}$-starved suspensions in Table 1.

\section{Table 1. Half-lives of $m R N A s$ from $K$. pneumoniae under various physiological conditions}

$K$. pneumoniae strain M5a1 was grown or derepressed for nif genes as described in the legend to Fig. 1. Chemical and functional half-lives of bulk mRNA were measured from the decay curves shown in Figs $1-3$ and $4(b)$. Functional decay of nif-specific mRNAs was measured using rifampicin as described in the legend to Fig. 4.

Condition

$\mathrm{NH}_{4}^{+}$-growth

$\mathrm{N}$-starved ( $3 \mathrm{~h}$ )

$\mathrm{NH}_{4}^{+}$added after

3 h N-starvation

$\mathrm{N}_{2}$-growth
Chemical half-life (min) Bulk mRNA

$$
\begin{array}{r}
4 \pm 1 \\
20 \pm 2 \\
9 \pm 1 \\
10 \pm 1
\end{array}
$$

Functional half-life (min)

$\begin{array}{rccc}\overbrace{\text { Bulk mRNA }} & \text { nifH } & \text { nifDK } & \text { nifJ } \\ 5 \pm 1 & - & - & - \\ 23 \pm 2 & 21 \pm 2 & 25 \pm 2 & 25 \pm 2 \\ 11 \pm 1 & 11 \pm 2 & 12 \pm 2 & 5 \pm 1 \\ 12 \pm 1 & - & - & -\end{array}$

stopped nifHDK and nif $J$ transcription and accelerated the degradation of nif $H D K$ and nif $J$ mRNAs, even in the absence of de novo RNA synthesis.

\section{DISCUSSION}

The stability of $K$. pneumoniae mRNAs was inversely related to the availability of combined nitrogen, and mRNA degradation rates rapidly responded to a change of $\mathrm{N}$-status, independently of transcription. Induction of a new operon was not required to increase the rate of mRNA degradation after a shift from nitrogen-starvation to nitrogen-sufficiency. Messenger RNA degradation was therefore controlled by the metabolic status of $K$. pneumoniae. This result 


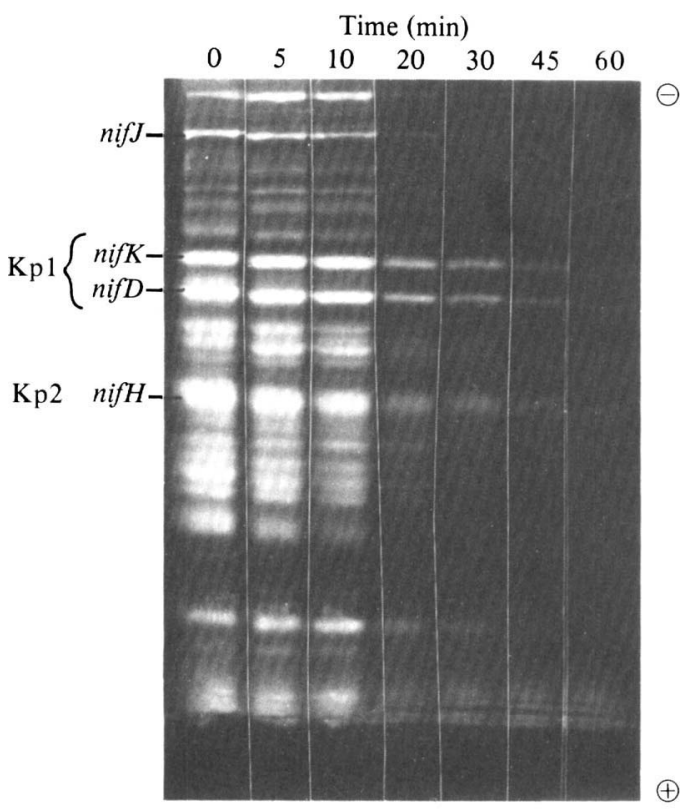

Fig. $4(a)$

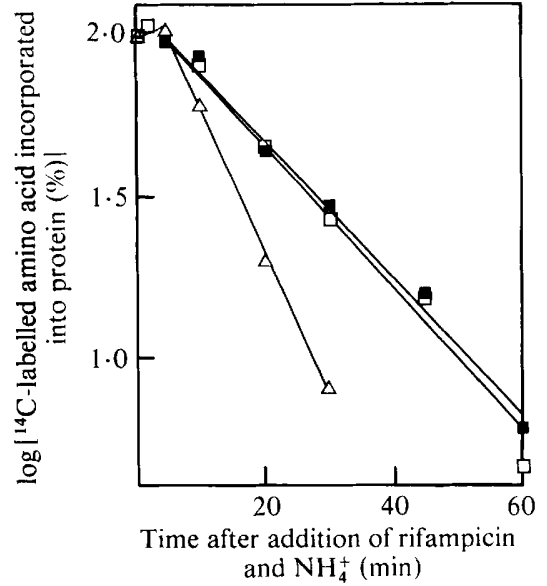

Fig. 4(b)

Fig. 4. Functional decay of nif-specific mRNAs following the addition of $\mathrm{NH}_{4}^{+}$and rifampicin to $\mathrm{N}$ starved $K$. pneumoniae. A culture of $K$. pneumoniae was derepressed for nif as described in Methods. After $3 \mathrm{~h} \mathrm{~N}$-deprivation $\left(\mathrm{NH}_{4}\right)_{2} \mathrm{SO}_{4}$ and rifampicin were added and the rate of protein synthesis determined from pulse-labelling with ${ }^{14} \mathrm{C}$-labelled amino acids as described in Methods. Samples were electrophoresed and the gels autoradiographed to allow identification of the nifHDK and $J$ products $(a)$. The intensity of these peaks was determined by microdensitometry and the peaks corresponding to Kpl (G), $\mathrm{Kp} 2(\square)$ and $J(\triangle)$ integrated. Semi-logarithmic plots $(b)$ of these data were used to determine the functional half-life of these nif mRNAs.

agrees with the hypothesis that macromolecular syntheses and degradation are under metabolic control, that is, are regulated by the concentration of some specialized metabolites (Tomkins, 1975; Danchin, 1979). The half-life of $K$. pneumoniae mRNA changed dramatically between growth rates of 0.23 and 0.63 doublings $\mathrm{h}^{-1}$. This result conflicts with an earlier concept that mRNA turnover does not change with growth rate (Pato \& von Mayenberg, 1970). However, these authors had noticed a possible trend towards longer half-lives at growth rates below 0.6 doublings $\mathrm{h}^{-1}$, a trend which we confirm in the case of $K$. pneumoniae.

Amino acid starvation elicits a stringent response of $K$. pneumoniae with a rise in ppGpp concentration (Riesenburg \& Kari, 1981; D. Kahn, M. Hawkins \& R. R. Eady, unpublished observations). The level of ppGpp is significantly higher in $\mathrm{N}_{2}$-grown cells than in $\mathrm{NH}_{4}^{+}$-grown cells (Kleiner \& Phillips, 1980). Levels of ppGpp, like mRNA stability, depend on the N-status of $K$. pneumoniae. This does not necessarily imply that ppGpp controls the rate of mRNA degradation, since other parameters including energy charge and the ADP/ATP ratio show significant differences between $\mathrm{N}_{2}-$ and $\mathrm{NH}_{4}^{+}$-supported growth (Upchurch \& Mortenson, 1980; Marriot et al., 1981). The function of ppGpp in stringent control itself it presently questioned (Spadaro et al., 1981). Therefore this topic requires further investigation.

This study bears particular relevance to the understanding of nif derepression in $K$. pneumoniae. Although all nif $\mathrm{mRNAs}$ have been initiated $20 \mathrm{~min}$ after $\mathrm{NH}_{4}^{+}$deprivation, nitrogenase activity does not appear until 60 min later (Collmer \& Lamborg, 1976). Nitrogenase is a complex enzyme that consists of two components, the Mo-Fe protein $(\mathrm{Kpl})$ and the $\mathrm{Fe}$ protein (Kp2) (Eady \& Smith, 1979). Nitrogenase polypeptides are not active per se, but are activated in processes involving several genes including nif $B$, nif $N$ and nif $E$ for the synthesis or the insertion of the $\mathrm{Fe}-\mathrm{Mo}$ cofactor of $\mathrm{Kp} 1$, and nif $M$ for the activation of $\mathrm{Kp} 2$ (Roberts et al., 1978). Moreover, a nif-specific electron transport chain is necessary for nitrogenase activity in 
vivo (Hill \& Kavanagh, 1980). The complete system is apparently built up in a slow fashion. In this context, one understands the need for more stable mRNAs if nitrogenase is to be expressed and $\mathrm{N}$-starvation overcome.

The stability of nif $H D K$ and nif $J$ mRNAs paralleled the stability of bulk mRNAs. Thus, their degradation was accelerated upon a shift from $\mathrm{N}$-starvation to $\mathrm{N}$-sufficiency. Functionally, nif $J$ mRNA appeared to be degraded faster (half-life $5 \pm 1 \mathrm{~min}$ ) than nifHDK mRNA in the presence of $\mathrm{NH}_{4}^{+}$(half-life 11-12 min). Our experiments could not rule out the possibility of some translational control of nif expression after the addition of $\mathrm{NH}_{4}^{+}$.

While this paper was in preparation, two reports provided data on the unusual stability of nif mRNAs. The first report (Houmard \& Bogusz, 1981) dealt with the functional stability of nif $H D K$, nif $J$, nif $U$ and nif $F$ mRNAs during growth of $K$. pneumoniae on $\mathrm{N}_{2}$. Although these authors did not quantify the stability of nif mRNAs, they showed that in their conditions (growth on $\mathrm{N}_{2}$ ) the nif mRNAs studied are more stable than bulk mRNAs. We did not measure the functional stability of nif mRNAs under their conditions. In our conditions, however (Nstarvation without growth), the nif mRNAs studied were as stable as bulk mRNAs. This discrepancy is not understood, but since we have shown that the stability of mRNAs depends on the $\mathrm{N}$-status of the culture, these differences may have arisen from the use of cultures with different $\mathrm{N}$-status, or from the use of a relatively long pulse-labelling time $(15 \mathrm{~min})$ by these workers. The second paper (Kaluza \& Hennecke, 1981) reported both chemical and functional half-lives of nifHDK mRNA. They determined the stability of this mRNA directly by hybridization to the plasmid pSA30 which carried $K$. pneumoniae nif $H, D$, and $K$ genes (Cannon et al., 1979). The data they obtained using $\mathrm{NH}_{4}^{+}$-limited batch cultures in the early stages of nif derepression are in good agreement with the data reported here. In this report we present further evidence extending their findings to nif $J$ mRNA and bulk mRNAs.

This work and a previous paper (Kahn et al., 1982) allow us to propose a new interpretation of the data of Collmer \& Lamborg (1976). These authors compared the timings of chloramphenicol and rifampicin inhibition of nitrogenase derepression to evaluate the length of the last nif operon expressed after ammonium starvation. They deduced it to be 20000 nucleotides long. Since no nif operon exceeds 6000 nucleotides (Riedel et al., 1979), 'transcriptional mapping' fails in the case of nif. One reason is that chloramphenicol inhibits the activation of Kpl (Kahn et al., 1982), the rate-limiting process for the synthesis of active nitrogenase during early derepression $(R . R$. Eady, unpublished results). Moreover, nif specific products involved in the activation of nitrogenase have to build up before nitrogenase activity can appear. Thus, one should not use 'transcriptional mapping' whenever polypeptides under study are not active per se and undergo some activation process. Collmer \& Lamborg (1976) also demonstrated that $\mathrm{NH}_{4}^{+}$curtails nitrogenase synthesis faster than rifampicin. They postulated a new target for the regulation of nif by $\mathrm{NH}_{4}^{+}$at a locus other than the operator. Here we show that $\mathrm{NH}_{4}^{+}$accelerates the degradation of mRNAs, including nif mRNAs. Since prolonged nif-specific syntheses are required before nitrogenase activity can appear, premature repression of nif by $\mathrm{NH}_{4}^{+}$followed by rapid mRNA degradation will prevent the appearance of nitrogenase activity. This accounts for the rapid arrest of nitrogenase synthesis after the addition of $\mathrm{NH}_{4}^{+}$compared with rifampicin. In the case of nif $H D K$, expression is regulated solely by transcriptional control (Kaluza \& Hennecke, 1981).

We thank Dr C. Kari for communicating results on the stringent response of $K$. pneumoniae prior to publication, Drs F. Cannon, J. Dénarié, R. A. Dixon, M. Iaccarino, C. Kennedy and B. E. Smith and Professor J. R. Postgate for helpful discussions and constructive criticism of the manuscript. One of us (D.K.) was a recipient of a longterm EMBO fellowship.

\section{REFERENCES}

BREMER, H. \& YUAN, D. (1968). Uridine transport and incorporation into nucleic acids in Escherichia coli. Biochimica et biophysica acta 169, 21-34.

BRILL, W. J. (1979). Regulation of nitrogen fixation. In

A Treatise on Dinitrogen Fixation, Section II, pp. 765798. Edited by R. W. Hardy, F. Bottomley \& R. C. Burns. New York: John Wiley.

Cannon, F. C. (1980). Genetic studies with diazo- 
trophs. In Methods for Evaluating Biological Nitrogen Fixation, pp. 367-413. Edited by F. J. Bergersen. New York: John Wiley.

Cannon, F. C., Dixon, R. A., Postgate, J. R. \& Primrose, S. B. (1974). Chromosomal integration of nitrogen fixing genes in Escherichia coli. Journal of General Microbiology 80, 227-239.

Cannon, F. C., Riedel, G. E. \& Ausubel, F. M. (1979). Overlapping sequences of Klebsiella pneumoniae nif DNA cloned and characterised. Molecular and General Genetics 174, 59-66.

Collmer, A. \& Lamborg, M. (1976). Arrangement and regulation of the nitrogen fixation genes in Klebsiella pneumoniae studied by derepression kinetics. Journal of Bacteriology 126, 806-813.

Danchin, A. (1979). Is a metabolic control for the doubling of the macromolecule synthesising machine possible? Biochimie 61, 45-50.

EADY, R. R. \& SMITH, B. E. (1979). Physico-chemical properties of nitrogenase and its components. In $A$ Treatise on Dinitrogen Fixation, Section II, pp. 399 490. Edited by R. W. Hardy, F. Bottomley \& R. C. Burns. New York: John Wiley.

EADY, R. R., KAHN, D. \& HaWkins, M. (1981). Metabolic control of Klebsiella pneumoniae mRNA. Significance to nif regulation by $\mathrm{NH}_{4}^{+}$. In Current Perspectives in Nitrogen Fixation, p. 443. Edited by A. H. Gibson \& W. E. Newton. Canberra: Australian Academy of Science.

Elmerich, C., Houmard, J., Sibold, L., Manheimer, L. \& CHARPIN, N. (1978). Genetic and biochemical analysis of $\mathrm{Mu}$ DNA integration into Klebsiella pneumoniae nitrogen fixation genes. Molecular and General Genetics 165, 181-189.

ForChHAMMER, J. \& KJELdGaARD, N. O. (1967). Decay of messenger RNA in vivo in a mutant of Escherichia coli 15. Journal of Molecular Biology 24, 459-470.

Hill, S. \& KaVanaGH, E. (1980). Roles of nif $F$ and nif $J$ gene products in electron transport to nitrogenase in Klebsiella pneumoniae. Journal of Bacteriology 141, 470-475.

Hirashima, A. \& Inouye, M. (1973). Specific biosynthesis of an envelope protein of Escherichia coli. Nature, London 242, 405-407.

Houmard, J. \& Bogusz, D. (1981). Kinetic study of the expression of Klebsiella pneumoniae nitrogen fixation (nif) genes under conditions of inhibited transcription. Biochemical and Biophysical Research Communications 100, 1237-1244.

Ixemura, T., Itoh, S., Post, L. E. \& Nomura, M. (1979). Isolation and characterisation of stable hybrid mRNA molecules transcribed from ribosomal protein promoters in E. coli. Cell 18, 895-903.

JACOBSON, L. A. \& JEN-JACOBSON, L. (1980). Control of protein synthesis in $E$. coli: strain differences in control of translational initiation after energy source shift-down. Journal of Bacteriology 142, 888-898.

KaHN, D., Hawkins, M. \& EADY, R. R. (1982). Nitrogen fixation in Klebsiella pneumoniae: nitrogenase levels and the effect of added molybdate on nitrogenase derepressed under molybdenum deprivation. Journal of General Microbiology 128 , 779-787.

KaluZa, K. \& Hennecke, H. (1981). Regulation of nitrogenase messenger RNA synthesis and stability in Klebsiella pneumoniae. Archives of Microbiology 130, 38-43.

Kleiner, D. \& Phillips, S. (1980). Relative levels of guanosine 5'-diphosphate 3'-diphosphate (ppGpp) in some $\mathrm{N}_{2}$-fixing bacteria during derepression and repression of nitrogenase. Archives of Microbiology 128, 341-342.

KLIPP, W. \& PÜHLER, A. (1981). Identification of gene products encoded by the Klebsiella nif-region. In Current Perspectives in Nitrogen Fixation, pp. 397-398. Edited by A. H. Gibson \& W. E. Newton. Canberra: Australian Academy of Sciences.

LAEMMLI, U. K. (1970). Cleavage of structural proteins during the assembly of the head of bacteriophage T4 Nature, London 227, 680-685.

LEAL, J. (1976). Effect of glucose starvation on the expression of transferred tox genes in Escherichia coli K 12 zygotes. Molecular and General Genetics 147, 54 58.

LINDAHL, L. \& FORCHHAMMER, J. (1969). Evidence for reduced breakdown of messenger RNA during blocked transcription or translation in Escherichia coli. Journal of Molecular Biology 43, 593-606.

Marriott, I. D., Dawes, E. A. \& Rowley, B. I. (1981). Effect of growth rate and nutrient limitation on the adenine nucleotide content, energy charge and enzymes of adenylate metabolism in Azotobacter beijerinckii. Journal of General Microbiology 125, 375 382.

Merrick, M., Filser, M., Kennedy, C. \& Dixon, R. (1978). Polarity of mutations induced by insertions of transposons $\operatorname{Tn} 5, \operatorname{Tn} 7$ and $\operatorname{Tn} 10$ into the nif gene cluster of Klebsiella pneumoniae. Molecular and General Genetics 165, 103-111.

Pato, M. L. \& von Meyenburg, K. (1970). Residual RNA synthesis in Escherichia coli after inhibition of initiation of transcription by rifampicin. Cold Spring Harbor Symposia on Quantitative Biology 35, 497504.

Pollock, M. R. (1963). The differential effect of actinomycin $D$ on the biosynthesis of enzymes in Bacillus subtilis and Bacillus cereus. Biochimica et biophysica acta 76, 80-93.

Riedel, G. E., Ausubel, F. M. \& Cannon, F. C (1979). Physical map of chromosomal nitrogen fixation (nif) genes of Klebsiella pneumoniae. Proceedings of the National Academy of Sciences of the United States of America 76, 2866-2870.

RIESENBURG, D. \& KARI, C. (1981). Isolation and characterisation of prototrophic relaxed mutants of Klebsiella pneumoniae. Molecular and General Genetics 181, 476-483.

Roberts, G. P., Macneil, T., Macneil, D. \& Brill, W. J. (1978). Regulation and characterisation of protein products coded by the nif (nitrogen fixation) genes of Klebsiella pneumoniae. Journal of Bacteriology 136, 267-279.

SANChez DE Rivas, C. \& Mendez, B. S. (1977). Unusual stability and translation kinetics of an Escherichia coli lac messenger RNA. Molecular and General Genetics 156, 229--232.

SCHLESSINGER, D. (1972). Longevity and translation yield of mRNA. In The Mechanism of Protein Synthesis and its Regulation, pp. 441-464. Edited by L. Bosch. Amsterdam: North Holland.

Spadaro, A., Spena, A., Santonastaso, V. \& Donini, 
P. (1981). Stringency without ppGpp accumulation. Nature, London 291, 256-258.

Tomkins, G. M. (1975). The metabolic code. Biological symbolism and the origin of intercellular communication is discussed. Science 189, 660-673.

UPChuRCh, R. G. \& MORTENSON, L. E. (1980). In vivo energetics and control of nitrogen fixation: changes in the adenylate energy charge and the adenosine $5^{\prime}$ diphosphate/adenosine 5 -triphosphate ratio of cells during growth on dinitrogen versus growth on ammonia. Journal of Bacteriology 143, 274284. 